\title{
Legal Legitimacy of Tax Recommendations Delivered by the IMF in the Context of 'Article IV Consultations'
}

\author{
Sophia Murillo López*
}

\begin{abstract}
This contribution examines the legal legitimacy of 'Article IV Consultations' performed by the IMF as part of its responsibility for surveillance under Article IV of its Articles of Agreement. The analysis focuses on tax recommendations given by the Fund to its member countries in the context of Consultations. This paper determines that these tax recommendations derive from a broad interpretation of the powers and obligations that have been agreed to in the Fund's Articles of Agreement. Such an interpretation leads to a legitimacy deficit, as member countries of the Fund have not given their state consent to receive recommendations as to which should be the tax policies it should adopt.
\end{abstract}

Keywords: legitimacy, International Monetary Fund (IMF),

Article IV Consultations, tax recommendations, global tax governance

\section{Introduction}

\subsection{The IMF's 'Article IV Consultations'}

Since its incorporation, the International Monetary Fund ('IMF' or the 'Fund') has had as its primary objectives 'the wish to promote international monetary cooperation and exchange rate stability, to assist in the establishment of a multilateral system of payments, to assist in the elimination of foreign exchange restrictions and to provide temporary (i.e., short-term) assistance to correct balance of payments imbalances'. ${ }^{1}$ To achieve these primary objectives, the IMF performs its work on three core fronts: (i) surveillance, i.e., monitoring the economic and financial policies of its member countries

Sophia Murillo López, LL.M, is an external PhD candidate at the Erasmus University Rotterdam and a member of the 'Fiscal Autonomy and its Boundaries' research programme. I am thankful to Professor A.C.G.A.C. de Graaf, LL.M., Ph.D., and I.J. Mosquera Valderrama, LL.M., Ph.D., who provided the expertise that greatly assisted the research. I am also grateful to Sascha Huijser-Grievink, LL.M, for her assistance in improving the manuscript. Opinions expressed and any mistakes that one may encounter in this journal article are of the author only.

1. See Art. 1, Articles of Agreement of the International Monetary Fund, 27 December 1945, 2 UNTS 39 (hereinafter 'Articles of Agreement'). The full text of the Articles of Agreement is available at: <https://imf. org/external/pubs/ft/aa/> (last visited 27 September 2016). to ensure sound economic growth; (ii) lending, i.e., providing loans to member countries to resolve problems connected to their balance of payments (such as payments to international creditors, the building of international reserves and measures to stabilise currencies) and iii) technical assistance, i.e., providing member countries with practical assistance in financial and economic affairs. $^{2}$

The first of these core fronts, surveillance, comprises both multilateral and bilateral surveillance activities by the Fund. Multilateral surveillance focuses on assessing the multidimensional features of the global and regional economy, monitoring economic trends and analysing the effect of member countries' policies on the wider economy. Reports issued in the framework of multilateral surveillance include the World Economic Outlook, the Global Financial Stability Report and Fiscal Monitor. ${ }^{3}$

Bilateral surveillance, on the other hand, takes the form of 'Article IV Consultations' as they are performed under Article IV (Obligations Regarding Exchange Arrangements) of the Fund's Articles of Agreement. ${ }^{4}$ The IMF's work during Consultations involves conducting regular, often annual, monitoring of its 189 member countries' individual economies. ${ }^{5}$ Consultations are generally aimed at giving the Fund's views on how individual countries can ensure economic growth and promote international monetary stability, as well as

2. G. Loibl, 'International Economic Law', in M.D. Evans (ed.), International Law (2010) 722, at 725.

3. For the World Economic Outlook, see <http://imf.org/external/pubs/ft/ weo/2016/02/> (last visited 27 September 2016). The Global Financial Stability Report can be consulted at: <http://imf.org/external/pubs/ft/ gfsr/index.htm> (last visited 27 September 2016). For Fiscal Monitor, see <www.imf.org/en/publications/fm> (last visited 27 September 2016).

4. For the purpose of this contribution, I will refer to Art. IV of the Articles of Agreement of the IMF as 'Art. IV', and to the IMF's Art. IV Consultations as 'Consultations'. According to the information published by the IMF, available at: <http://imf.org/external/about.htm>, the Fund conducted over 130 consultations in 2013, 132 consultations in 2014 and 124 consultations in 2015.

5. The full list of the organisation's member countries is available at: <https://www.imf.org/external/np/sec/memdir/memdate.htm> (last visited 27 September 2016). 
advising them on risks that may threaten the international monetary system. ${ }^{6}$

In practice, a Consultation process begins with an official visit (known as a 'mission' in IMF jargon) to a member country. During this mission, IMF staff seek to collect economic, financial and monetary information on the relevant country and to discuss the country's economic development and policies with government officials. The main conclusions of Consultations are included in a report compiled by the staff. This report is then presented to the managing director (as chairman of the Executive Board), who is responsible for encapsulating the views of executive directors and presenting the summary to the country's government officials. ${ }^{7}$ The Fund conducted over 130 Consultations in 2013, 132 Consultations in 2014 and 124 Consultations in $2015 .{ }^{8}$

\subsection{Blurred Legitimacy}

Individual recommendations given by the IMF to countries in the context of Consultations usually also include proposals relating to tax policies that the Fund considers should be modified in national tax systems. It is arguable, however, whether countries have consented to receive recommendations from the Fund as to their tax systems. This matter is of particular relevance considering that, theoretically, all countries have tax autonomy to design their tax systems. ${ }^{9}$

Although member countries of the Fund have given their state consent to be part of the Fund (validated through the ratification of the Fund's Articles of Agreement), the scope of powers of the organisation as well as the obligations derived from their condition as member countries must be interpreted in accordance with the treaty provisions and general principles of treaty interpretation.

For the purpose of the examination, a literal reading of Article IV revealed that this provision (in Section 3) enables the Fund to oversee the compliance of member countries with the obligations set forth in Section 1 of the Article, which bind member countries 'to collaborate with the Fund and other members to assure orderly exchange arrangements and to promote a stable system of exchange rates'. ${ }^{10}$ Under the same section of the Article, each member country is particularly directed to:

(i) endeavor to direct its economic and financial policies toward the objective of fostering orderly economic growth with reasonable price stability, with due regard to its circumstances;

(ii) seek to promote stability by fostering orderly underlying economic and financial conditions and a monetary system that does not tend to produce erratic disruptions; ${ }^{11}$

Hence, even though it may be derived from Article IV that the Fund has the power to monitor its member countries' economic and financial policies, it is questionable whether this power enables the Fund to deliver its members with specific tax recommendations that touch upon fundamental aspects of national tax systems. In principle, there are no legal consequences attached to non-compliance with the obligations set forth in Article IV, and, consequently, countries are not legally obliged to follow the tax recommendations given by the Fund during a Consultation. Yet a non-cooperating country could be affected by consequences other than those of a legal nature, such as a downgrading of its reputation by the international community. ${ }^{12}$

Hence, considering the role that the IMF has in global economic governance, I have concerns about the legitimacy of the tax recommendations under analysis. ${ }^{13}$ According to Franck, '[i]n the international context, legitimacy is achieved if - or to the extent that - those addressed by a rule, or by a rule-making institution, perceive the rule or institution to have come into being and to be operating in accordance with generally accepted principles of right process. ${ }^{14}$ Further, as rightly stated by Bodansky, '[w] hen international institutions were relatively weak, legitimacy was not a pressing issue. However, the aggregated powers that have since been conferred on these institutions to address collective problems mean that questions arise regarding their legitimacy.' ${ }^{15}$
6. According to the IMF, the international monetary system comprises 'the system of exchange rates and international payments that enables countries (and their citizens) to transact with each other'. More information on the work of the IMF is available at: <http://imf.org/external/ about.htm > (last visited 27 September 2016).

7. According to an IMF decision: 'It is expected that no later than sixtyfive days after the termination of discussions between the member and the staff, the Executive Board will reach conclusions and thereby complete the consultation under Article IV.' IMF, Decision on Bilateral and Multilateral Surveillance (N. 15203-(12/72)) (2012) in IMF, Selected Decisions and Selected Documents of the International Monetary Fund 37 (2014), at 27, (hereinafter '2012 Decision'). See also L. MartinezDiaz, 'Executive Boards in International Organizations: Lessons for Strengthening IMF Governance', IEO Background Paper, at 8 (2008).

8. See <http://imf.org/external/about.htm>

9. For the purpose of this contribution, I understand tax autonomy as the power that states have to define their tax policies, with the exclusion of those obligations acquired in treaties with other states and/or international organisations.

10. Art. IV Articles of Agreement.
11. Ibid.

12. For an analysis of public blacklisting by international organisations as a means of bringing about compliance, see J.C. Sharman, 'The Bark is the Bite: International Organizations and Blacklisting', 16 Review of International Political Economy 573 (2009).

13. This contribution is not aimed at analysing the role of the IMF in international governance. Numerous authors explain this theory; for that purpose see, among others: A Vetterlein and S Park (eds.), Owning Development: Creating Policy Norms in the IMF and the World Bank (2016); D. Swank, 'The New Political Economy of Taxation in the Developing World', 23 Review of International Political Economy 185 (2016); D. Bradlow, The Changing Role of the IMF in the Governance of the Global Economy and its Consequences, Paper prepared for the Annual Banking Law Update, University of Johannesburg, May 3, 2006.

14. T. Franck, 'The Emerging Right to Democratic Governance', 86 American Journal of International Law 46, at 51 (1992). See also T.M. Franck, The Power of Legitimacy among Nations (1990), for previous work by the author on international legitimacy.

15. D. Bodansky, 'The Concept of Legitimacy in International Law', in R. Wolfrum and V. Röben (eds.), Legitimacy in International Law (2008) 309 , at 309. 
Legitimacy, in that sense, is a fundamental principle to be pursued in the current context of globalisation and state coordination, as it guarantees that states' interests are not weakened by the actions of international organisations and related arrangements. ${ }^{16}$ In the case of the $\mathrm{IMF}$, legitimacy is a highly relevant objective, given the organisation's influence on the adoption of economic, financial and tax policies by its member countries.

At an individual level, a legitimacy deficit could also result in having citizens question their country's government officials on the motives underlying the adoption or derogation of certain tax policies, as per the recommendations flowing from a Consultation. Ultimately, 'in a democratic society, the payment of taxes also gives to the taxpayer the right to participate and to have a say in the design of the tax system', in accordance with the principle of 'no taxation without representation'. ${ }^{17}$

The following case may help to exemplify the delivery of tax policy recommendations by the Fund, within a Consultation: The Concluding Statement of the 2014 Article IV Mission for Costa Rica recommended, among other things, that the country move from a territorial system of income tax to a global system, as well as extending the General Sales Tax (GST) to include additional goods and services, and increasing the GST tax rate by $2 \%{ }^{18}$

The IMF's views on Costa Rica's fiscal policies remained consistent throughout the 2016 Consultation report. ${ }^{19}$ As a collateral effect, Costa Rican news media focused attention on the IMF recommendations, imply-

16. State coordination encompasses any form of dialogue between states to discuss and, to a certain extent, negotiate public policies falling within their scope of interest. State coordination may take various forms, ranging from legally constituted organisations or institutions to arrangements, such as meetings or forums, of a less formal nature (legally speaking). Collaterally, these organisations and arrangements produce actions that have effects on participating and, in some cases, even on non-participating states. State coordination is currently being demanded in all areas of governance, including environment, fisheries, trade, finance, tax, customs, human rights and law enforcement, to name but a few. Consequently, governance concerns that used to be regarded as solely territorial, and decided by a sovereign power, have now become global or regional concerns, and are hence of a multilateral nature.

17. I. Mosquera Valderrama, 'Legitimacy and the Making of International Tax Law: The Challenges of Multilateralism', 3 World Tax Journal, at 5 (2015).

18. IMF, Costa Rica: Concluding Statement of the 2014 Article IV Mission, 10 November 2014, available at: <http://imf.org/external/np/ms/ 2014/111014.htm> (last visited 27 September 2016). In this report, the IMF states: 'In particular, we support broadening the VAT base to include services and basic goods, the latter accompanied by actions to mitigate the impact on lower income households, as well as the move to a global income tax. If implemented, the plan will greatly enhance macro stability, thus stimulating growth...Although significant revenue gains may be accrued by reducing tax exemptions and other special treatments, the substantial budget consolidation required will likely demand increases in tax rates in the future. Thus the mission recommends raising the VAT rate from 13 to 15 percent gradually and increasing marginal tax rates on higher brackets as part of the introduction of a global income tax, thereby addressing also distributional concerns. The government has confirmed its willingness to raise VAT rates in steps starting in 2016 consistent with the consolidation recommended by the mission.'

19. IMF, Costa Rica - Concluding Statement of the 2016 Article IV Mission, 7 March 2016, available at: <http://imf.org/external/np/ms/ 2016/030716.htm> (last visited 24 September 2016). ing both that the country is required to follow these recommendations and that an urgent need for tax reform exists to avoid possible disaster in the Costa Rican economy. ${ }^{20}$ Government officials also sought to justify taxrelated bills on the grounds that the IMF has 'approved of' and 'urges' the country to adopt the policies proposed in those bills. ${ }^{21}$

In this case the measures recommended by the IMF concerned intrinsic elements of the country's tax structure. The adoption of the recommendations by Costa Rica (which will most likely occur after the corresponding bills have been approved by Congress) will possibly have major effects, not only from an economic, but also from a social perspective. The $2 \%$ increase in the GST tax rate (from the current $13 \%$ to $15 \%$ ) can be expected to have an impact on households' disposable income, and this could, in turn, adversely affect economic inequality ratios. ${ }^{22}$

The case of Costa Rica should not be seen as isolated, to the extent that IMF Consultation reports consistently include tax recommendations on issues ranging from tax administration to member countries' overall tax structures. Indeed, Seabrooke has extensively studied the content of the Fund's tax advice to countries, determining that the organisation has a catalogue of ' $\mathrm{IMF}$-friendly' tax reform policies. ${ }^{23}$ According to this author:

$[\mathrm{I}] \mathrm{n}$ the $[\operatorname{tax}]$ policy area the Fund has a clear norm expressed as an 'IMF friendly' tax policy mix. Throughout the post-war period the Fund has encouraged its member states to integrate themselves into a free trading international political economy. It consistently advocates moving tax burdens away from international trade and import and export taxes, as well as taxes on capital income, and towards broad domestic sources, particularly consumption taxes. ${ }^{24}$

20. See <http://qcostarica.com/costa-rica-receptive-to-imfs-vat-calls/>, $<$ http://qcostarica.com/imf-time-is-running-out-for-costa-rica/> (last visited 24 September 2016); <http://player.gfrvideo.com/gnelfinanciero/videofmipidehacerlareformafiscalenel2016-195110.html> (last visited 27 September 2016).

21. See <http://gobierno.cr/fmi-dio-aval-a-politica-monetaria-de-costa-rica -y-reitero-urgencia-de-reforma-fiscal/\#more-10377> (last visited 20 September 2016). See also <http://informa-tico.com/4-08-2015/ propone-fmi-racionalizar-gasto-publico-costa-rica-i-parte> (last visited 20 September 2016); <http://elfinancierocr.com/finanzas/FMI-CostaRica-consolidacion-ambiciosa_0_626337367.html> (last visited 24 September 2016).

22. Regarding the effects of implementing these and other reforms, see $F$. Rodríguez Garro, F. Sancho Mora \& R. Fonseca Hernández, ‘Efectos de la Reforma Tributaria en Costa Rica: Implementación del IVA', 70 Revista Centroamericana de Administración Pública 273 (2016); M. Loría and C. Umaña, 'La propuesta de consolidación fiscal: algunas reflexiones para su discusión', 1 Serie Programa Visión ACADEMIACA (2014).

23. See L. Seabrooke, 'Bitter Pills to Swallow: Legitimacy Gaps and Social Recognition of the IMF Tax Policy Norm in East Asia', in A Vetterlein and S Park (eds.), Owning Development: Creating Policy Norms in the IMF and the World Bank (2016), at 151. Also see A. Broome and L. Seabrooke, 'Seeing like the IMF: Institutional change in small open economies', 14:4 Review of International Political Economy 576, at 583 (2007).

24. Seabrooke, above n. 23, at 147. 


\subsection{Aim and Methodology}

Departing from the above, this contribution aims to examine the legal legitimacy of tax recommendations delivered by the IMF to individual countries within a Consultation procedure. The question addressed is to what extent are these tax recommendations legally legitimate? In order to answer this question, the ideas of legal legitimacy elaborated by Bodansky will be used. ${ }^{25}$

The approach I am undertaking is innovative, since no research has been found that specifically analyses the legitimacy of tax recommendations delivered by the IMF in the context of Article IV Consultations. ${ }^{26}$ For two reasons, this analysis does not seek to provide an exhaustive or comprehensive list of all the legitimacy matters that could be connected to the IMF, its role in global governance or of the IMF Consultations in general. Additionally, this contribution does not attempt to analyse the legitimacy of the Consultation Procedures specifically undertaken by the IMF in Costa Rica or any other country.

The corresponding examination will be discussed in four sections. After the introduction, comprising the first section, the second section provides a general overview of the IMF. The third section presents the analysis of the legitimacy of tax recommendations contained in Consultation reports. The fourth and final section summarises the results and conclusions of the analysis developed in the contribution.

D. Bodansky, 'The Legitimacy of International Governance: A Coming Challenge for International Environmental Law?', 93 The American Journal of International Law 596 (1999).

26. As indicated earlier in this paper, several authors (e.g., see Seabrooke, above n. 23; E. Riesenhuber, The International Monetary Fund Under Constraint: Legitimacy of its Crisis Management (2001); T. Bernes, 'IMF Legitimacy and Governance Reform: Will the G20 Help or Hinder?', Remarks delivered at the G20 Seoul International Symposium: Toward the Consolidation of G20 Summits - from Crisis Committee to Global Steering Committee, September 28-29, 2010; A. Weber, 'Legitimacy of IMF Endangered', Deutsche Bundesbank (2009); J. Best, 'Legitimacy Dilemmas: The IMF's Pursuit of Country Ownership', 28 Third World Quarterly 469 (2007)) have analyzed the legitimacy of the IMF. Other authors have also studied the legitimacy of IMF Surveillance, in general terms (see M. Mussa, 'IMF Surveillance', 87 The American Economic Review 28 (1997); R. Lavigne, P. Maier \& E. Santor, 'Renewing IMF Surveillance: Transparency, Accountability, and Independence', 4 The Review of International Organizations 29 (2009); M. Edwards, K. Coolidge \& D. Preston, 'Who Reveals? Transparency and the IMF's Article IV Consultations', Paper presented at the MidWest Political Science Association, 31 March 2011), as well as the output legitimacy of specific tax measure implemented by countries, following IMF's recommendations (see e.g., B. Momani, 'Assessing the Utility of, and Measuring Learning from, Canada's IMF Article IV Consultations', 39 Canadian Journal of Political Science 249 (2006); M. Edwards and S. Senger, 'Listening to Advice: Assessing the External Impact of IMF Article IV Consultations of the United States, 2010-2011', 16 International Studies Perspectives 312 (2015)); M. Weisbrot and H. Jorgensen, 'Macroeconomic Policy Advice and the Article IV Consultations: A European Union Case Study', Center for Economic and Policy Research (2013).

\section{The IMF: General Description}

State coordination in economic areas developed particularly rapidly towards and immediately after the end of the Second World War. This included the creation of three important international institutions during the Bretton Woods Conference, held in Bretton Woods, New Hampshire, United States, in 1944: the International Monetary Fund (IMF), the International Bank for Reconstruction and Development (better known as the World Bank) and the General Agreement on Tariffs and Trade (GATT). ${ }^{27}$ The 44 states participating in the conference had as an objective the creation of an international economic system that would avoid the economic and financial distortions that had led to the Great Depression in the 1930s. ${ }^{28}$ Further, the international regulations and institutions created during this conference continue to constitute the backbone of the current economic system. ${ }^{29}$

The IMF currently has 189 member countries and is governed by four main organs: the Board of Governors, the Executive Board, the staff and the managing director. ${ }^{30}$ Christine Lagarde, from France, has been managing director and chairman of the Executive Board since 5 July 2011. In addition, the Fund has 17 departments carrying out its surveillance, policy, analytical and technical work.

The Board of Governors is the highest decision-making body in the IMF, and is composed of one governor and one alternate governor for each member country. ${ }^{31}$ Under Article XII, Section 2(b), however, 'the Board of Governors may delegate to the Executive Board authority to exercise any powers of the Board of Governors, except the powers conferred directly by this Agreement on the Board of Governors. ${ }^{32}$ Under Section 2(g) of the same Article, 'The Board of Governors, and the Executive Board to the extent authorized, may adopt such rules and regulations as may be necessary or appropriate to conduct the business of the Fund.' Therefore, the Board of Governors can be said to hold the supreme powers (functional and regulatory) of the Fund.

The Board of Governors and the managing director of the Fund are responsible for electing the Executive Board, which is composed of 24 directors who meet on a
27.

29. in the establishment of the Organisation for Economic sation for European Economic Cooperation (OEEC) and in the G20's sation for European Economic Cooperation (OEEC) and in the G20's
decision in 2009 to create the Financial Stability Board as the successor to the Financial Stability Forum. See P. Subacchi and S. Pickford, International Economic Governance: Last Chance for the G20? (2015).

30. Art. XII Articles of Agreement.

31. Ibid.

32. Ibid. 
weekly basis to discuss the Fund's regular dealings. ${ }^{33}$ Executive Board voting is based on the number of votes that each director has; this, in turn, depends on the quotas paid by member countries to the Fund. ${ }^{34}$ The managing director is the head of the organisation's staff and chairman of the Executive Board. The managing director is appointed by the Executive Board for a renewable term of 5 years and is assisted by a first deputy managing director and three deputy managing directors. ${ }^{35}$

Since the Board Reform Amendment of 26 January 2016, member countries have been able to decide on their quota increases. This is especially relevant because voting shares may vary according to new quota increases. Hence, as stated by the Fund, 'Unlike the General Assembly of the United Nations, where each country has one vote, decision making at the IMF was designed to reflect the relative positions of its member countries in the global economy.' ${ }^{36}$ This voting system differs from the general practice in the majority of international organisations, where each member is likely to have one vote only. As a result, unlike equal voting systems, the IMF presents a different arrangement enabling economically powerful countries to exert control over the IMF. The Articles of Agreement include details of the procedure applying to amendments. Under this procedure, a proposal of amendment may be presented by a member, a Governor or the Executive Board. The proposal is then communicated to the chairman of the Board of Governors for approval by a majority of votes cast. Once the proposal has been approved by the Board of Governors, the Fund has to ask each member whether it accepts the proposed amendment. If three-fifths of the members, representing eighty-five percent of the total voting power, accept the proposed amendment, the Fund will certify the fact by addressing a formal communication to all members. ${ }^{37}$ Amendments enter into force for all members 3 months after the date of the formal communication, unless a shorter period is specified in a circular letter or telegram from the Fund.

IMF staff is currently spread over three main areas, aligned with the core work fronts of the organisation (surveillance, lending and technical assistance). As Consultations take place in the context of the IMF's surveillance work, this is the area on which this contribution will focus.

As mentioned earlier, the IMF undertakes both multilateral and bilateral surveillance. These activities influence the current panorama of taxation as they elaborate on recommendations to be followed by countries in for-

33. Ibid.

34. For more information on the voting powers, see <http://imf.org/ external/np/sec/memdir/eds.aspx> (last visited 30 September 2016).

35. See <http://imf.org/external/about/mgmt.htm> (last visited 30 September 2016).

36. Art. XII, Section 5 Articles of Agreement; <http://imf.org/en/About/ Factsheets/Sheets/2016/07/27/15/24/How-the-IMF-MakesDecisions> (last visited 30 September 2016).

37. Art. XXVIII (a) Articles of Agreement. In many countries, the procedures for acceptance of amendments are the same as those for treaty ratification. Ultimately, however, these procedures depend on the internal standards set by each member country for regulating the subject. mulating their tax systems and policies. The IMF's Fiscal Affairs Department is responsible for determining the tax policy advice given to countries. ${ }^{38}$ In the view of the organisation, the IMF's technical assistance on tax matters ensures the stability of countries by fostering the collection of tax revenues and enhances their overall economic and financial growth. As the Fund sees it:

Fiscal policy affects macroeconomic stability, growth, and income distribution. Citizens expect their governments to ensure value-for-money for public spending, a fair and efficient tax system, and transparent and accountable management of public sector resources.

The IMF has been a leading source of fiscal policy and management expertise worldwide. The IMF monitors and analyzes global fiscal trends and advises IMF member countries on fiscal issues directly. ${ }^{39}$

\section{Legal Legitimacy under Review}

\subsection{Introduction}

This section of the contribution aims to respond to the question, presented at the beginning of the contribution, of whether the tax recommendations given by the Fund in the context of Consultations are legitimate. As stated in Section 1 of this article, legitimacy is a long-ago and widely discussed subject among legal theorists, resulting in numerous definitions of the term. In agreement with Wolfrum: 'legitimacy is being used differently, although it mostly means to refer to the justification of authority, this notion being understood as the equivalent of having the power to take binding decisions or to prescribe binding rules'. ${ }^{40}$

For the purpose of this paper, the analysis will be carried out applying the knowledge elaborated by Bodansky in regard to legal legitimacy. In this author's view:

To the extent that authority is exercised at the international level by institutions rather than by international rules directly, then, in addition to general consent, we also need a concept of "legal legitimacy" "the condition of being in accordance with law or principle," as the Oxford English Dictionay puts it. Legal legitimacy is what connects an institution's continuing authority to its original basis in state consent. The authority of the International Court of Justice, for example, derives from its Statute, to which UN member states consented. And the Court's continuing authority depends on its acting in accordance with the Statute. If it went outside or against the

38. See <http://imf.org/external/np/exr/key/fiscal.htm> (last visited 30 September 2016).

39. Ibid.

40. R. Wolfrum, 'Legitimacy of International Law from a Legal Perspective: Some Introductory Considerations', in R. Wolfrum and V. Röben (eds.), Legitimacy in International Law (2008) 1, at 6. 
Statute, then its actions would lack legitimacy. ${ }^{41}$ [emphasis added]

As Bodansky rightly indicates, from a legitimacy perspective it is not sufficient for an international organisation to have 'general' consent from its member countries. 'General' consent refers to the consent given by countries to an ongoing system of governance, such as the ratification of a treaty that creates an international organisation. ${ }^{42}$ State consent, however, cannot be disregarded once a treaty enters into force. ${ }^{43}$ It continues to be highly relevant during the course of the work carried out by international organisations, provided that it is a filter to assess the said work and eventually hold accountable the organisation if it goes beyond the powers it has been granted. Following Bodansky, this connection between state consent and an institution's continuing authority is achieved through legal legitimacy. ${ }^{44}$ From the foregoing, the assessment of legal legitimacy will be performed taking into consideration the two following elements: (i) state consent and (ii) authority. Both of these elements are considered sine qua non conditions of legal legitimacy. The validation of state consent and authority should not be taken lightly, and a mistaken understanding could even lead to the conclusion that each of these elements can exist one without the other. To avoid falling into such grey areas I have made the following assumptions: ${ }^{45}$

The authority of an international organisation, and more specifically its continuing authority, is legitimate if the said authority is exercised in agreement with the consent given by the parties that give life to the organisation. Hence, for the purpose of the analysis, authority (first element of the analysis) refers to the powers or rights of an international organisation (in this case the IMF) to act (e.g., to give orders, make decisions and enforce obedience). State consent (second element of the analysis), understood as permission or an agreement by a sovereign country for something to happen or to do something, enables the authority of international organisations. ${ }^{46}$ The exercise of authority, without consent, is legally void and constitutes abuse of power or arbitrariness.

41. Bodansky, above n. 25, at 605 .

42. Ibid.

43. Indeed, authors such as Wolfrum explain that "[t]he consent of a State will undoubtedly be sufficient as a mechanism to invoke the legitimacy of [an] ... specific and static [obligation] [that] can be implemented by an isolated act or omission. The same is true even if the obligation is of a continuing nature but the commitment does not change over time as far as its substance and scope is concerned. There is, de facto, the danger, though, that the legitimizing effect of the original consent may fade over time. This would be particularly true if, due to changing circumstances, the burden of implementing a given obligation increased significantly'. R. Wolfrum, above n. 40, at 9 .

44. Bodansky, above n. 25, at 605

45. See Annex 2-Figure 1: Legal legitimacy Flow Diagram. I have elaborated a flow diagram that summarises my views on how to determine the legal legitimacy of acts by international organisations.

46. The Oxford English Dictionary defines consent as: 'permission for something to happen or agreement to do something'.
I argue that an international organisation has authority if it acts in accordance with an international treaty signed and ratified by the relevant parties. Contrarily, it would lack such authority if the acts of the international organisation fell outside the scope of powers granted to the organisation by the parties to an international treaty.

In regard to the above, I consider it important to provide a brief reference to the theories that have been extensively developed in international law about the competences of international organisations (in the next section). These theories help determine to what extent an act by an international organisation falls within or outside the scope of powers that the international organisation has.

\subsubsection{Some Notes Regarding the Competences of International Organisations}

Two main theories have been developed about the scope of powers of international organisations: the theory of attributed powers and the theory of implied powers.

The theory of attributed powers is based on the principle of speciality or the principle of attribution, presented in 1926 by the International Court of Justice (ICJ) on Furisdiction of the European Commission of the Danube. In its opinion, the Court responds to the question of the scope of the powers of the European Commission of the Danube, making clear that:

As the European Commission is not a State, but an international institution with a special purpose, it only has the functions bestomed upon it by the Definitive Statute with a viem to the fulfillment of that purpose, but it has power to exercise these functions to their full extent, in so far as the Statute does not impose restrictions upon it. ${ }^{47}$ [emphasis added]

This theory was also developed by the ICJ in 1996 in Legality of the Threat or Use of Nuclear Weapons, stating:

The Court need hardly point out that international organizations are subjects of international law which do not, unlike States, possess a general competence. International organizations are governed by the "principle of speciality", that is to say, they are vested by the States which create them with powers, the limits of which are a function of the common interests whose promotion those States entrust to them. ${ }^{48}$

In its opinions the Court establishes that the powers that international organisations have are restricted to those powers conferred by the states that create these organisations. Further, for the ICJ the powers of an international organisation are limited by the common interests

47. ICJ, Jurisdiction of the European Commission of the Danube, Advisory Opinion, 8 December 1927. The Convention establishing the Definitive Statute of the Danube was signed on 23 July 1921 pursuant to Article 349 of the Treaty of Peace of Versailles (and the corresponding articles of the other peace treaties concluded in 1919 and 1920).

48. ICJ, Legality of the Use by a State of Nuclear Weapons in Armed Conflict, Advisory Opinion, 8 July 1996. 
to be attained by it per the determination of the constitutive members.

Hence, according to the theory of attributed powers international organisations only have the powers bestowed upon them by member states in an international convention. Contrarily interpreted, an international organisation is not able to exercise powers that fall outside the scope of the functions it has been assigned in its legal instruments. The current text of Article 5 of the Treaty on the European Union serves as an example of this idea:

\section{Article 5}

1. The limits of Union competences are governed by the principle of conferral. The use of Union competences is governed by the principles of subsidiarity and proportionality.

2. Under the principle of conferral, the Union shall act only within the limits of the competences conferred upon it by the Member States in the Treaties to attain the objectives set out therein. Competences not conferred upon the Union in the Treaties remain with the Member States. ${ }^{49}$ [emphasis added]

In spite of the sovereignty protection involved in the theory of attributed powers, it has often been criticised in the literature for two main reasons. First, the theory is questioned as to its implications for the autonomy of international organisations as subjects having an independent will from that of their member states. ${ }^{50}$ Second, for practical reasons, it is objected that international organisations are 'living creatures', in a constant evolution, which would impede their founding members from foreseeing all the powers that will be required by international organisations for their operation. ${ }^{51}$ Following Klabbers, 'in those circumstances, the organization should not be limited by those powers granted to it upon its creation; instead, the organization must be allowed some flexibility. It must be allowed certain powers which, while not expressly granted, are granted by implication. ${ }^{52}$ This claim lays down the foundations of the theory of implied powers.

This second theory generally supports the idea that in addition to those powers expressly conferred on international organisations in their legal instruments, there are certain powers that may be implied from the functions and purposes that they have been assigned. The theory of implied powers has also been developed by the ICJ in its jurisprudence, stating that 'the necessities of international life may point to the need for organizations, in order to achieve their objectives, to possess subsidiary powers which are not expressly provided for in the basic instruments which govern their activities. ${ }^{53}$ Conse-

49. Art. 5 of the Treaty on the European Union.

50. J. Klabbers, An Introduction to International Institutional Law (2002), at 66 .

51. Ibid.

52. Ibid.

53. ICJ, Legality of the Use by a State of Nuclear Weapons in Armed Conflict, Advisory Opinion, 8 July 1996 quently, where an international organisation requires a specific capacity to fulfil and perform its objectives, that particular capacity is deemed as granted by its constitutive members although not expressly indicated in the organisation's constitutive documents. The doctrine of implied powers was applied by the Permanent Court of International Justice to the International Labour Organization in $1926 .{ }^{54}$ The ICJ also took recourse to this doctrine in 1949 when referring to the powers of the United Nations. ${ }^{55}$

In my view, regardless of the election of either theory, it can be generally concluded that international organisations have a limited competence to act (unlike states, which have been fully vested with rights, powers and obligations). It can also be settled that international obligations may act only in accordance with their legal powers, whether these powers are explicitly recognised in the text of the respective constituent treaty or because they derive from the functions and objectives of the organisation. Ultimately, what is at stake is the principle of consent, which continues to be an axiom of the political system and an implication of state autonomy. ${ }^{56}$

\subsection{Assessment}

\subsubsection{Article IV of the Articles of Agreement}

Consultations are performed by the Fund as part of its surveillance activities regulated under Article IV (Obligations Regarding Exchange Arrangements) of its Articles of Agreement. ${ }^{57}$

Under Section 1 of Article IV (General obligations of members), member countries have a general obligation 'to collaborate with [the Fund] and other members to assure orderly exchange arrangements and to promote a stable system of exchange rates. ${ }^{58}$ This general obligation is supported by four specific obligations (in the same section), which may be summarised as follows. Each member country is mandated to: (i) '... direct its economic and financial policies toward the objective of fostering orderly economic growth with reasonable price

54. ICJ, Competence of the International Labour Organization to Regulate, Incidentally, the Personal Work of the Employer, Advisory Opinion No. 13 of July 23rd, 1926 (Series B, No. 13, at 18-21).

55. See Reparation for Injuries Suffered in the Service of the United Nations, Advisory Opinion, ICJ Reports (1949), at 182-3; cf. Effect of Awards of Compensation Made by the United Nations Administrative Tribunal, Advisory Opinion, ICJ Reports (1954), at 57.

56. Following L. Henkin, 'state consent is the foundation of international law. The principle that law is binding on a [s]tate only by its consent remains an axiom of the political system, an implication of [s] tate autonomy.' L. Henkin, 'General Course on Public International Law', IV Recueil des Cours, at 46 (1989).

57. See Annex 1. It should be noted that Article IV was amended by the Second Amendment of the Articles of Agreement of the IMF in 1978. The surveillance functions were assigned to the Fund in the modifications introduced by this Second Amendment. Previously the Fund relied solely on Art. IV, Section 4(a) to either call on or recommend members to take certain action or refrain from taking action to achieve the objectives set out in this provision. Prior to the Second Amendment of Art. IV, Section 4(a), set forth a general obligation to collaborate as follows: 'Each member undertakes to collaborate with the Fund to promote exchange stability, to maintain orderly exchange arrangements with other members, and to avoid competitive exchange alterations.'

58. Art. IV, Section 1, Articles of Agreement. 
stability';59 (ii) 'seek to promote stability by fostering' economic, financial and monetary conditions; ${ }^{60}$ (iii) 'avoid manipulating exchange rates or the international monetary system', 61 and (iv) 'follow exchange policies compatible' with the commitments undertaken in the same section.

In order to ensure that member states fulfil their obligations under Section 1 of the Article, Section 3(a) establishes two different mandates for the Fund. First, it is impelled to 'oversee the international monetary system in order to ensure its effective operation', ${ }^{62}$ while, second, it is obliged to oversee members' compliance with obligations contained in Section 1 of Article IV. ${ }^{63}$

Accordingly, Section 3(b) of Article IV sets forth the specific obligations to be met by the Fund in seeking to fulfil the general obligations contained in Article IV, Section 3(a). Under this provision, the Fund is compelled to exercise 'firm surveillance' over members' exchange rate policies, as well as adopting principles to guide members with respect to these policies. ${ }^{64}$ Article IV, Section 3(b), also creates obligations to be complied with by the Fund's member countries and that, in principle, enable the Fund to accomplish its surveillance functions. In this sense, members are required to (i) provide the Fund with all necessary information to exercise its surveillance and (ii) to consult with the Fund, as required by the organisation, on their exchange rate policies. $^{65}$

Although the IMF's surveillance activities are specifically regulated under Section 3 of Article IV, Section 1 becomes relevant in view of the reference made to it in Section 3(a).

\subsubsection{State Consent}

International law governs relations between independent States. The rules of law binding upon States therefore emanate from their own free will as expressed in conventions or by usages generally accepted as expressing principles of law and established in order to regulate the relations between these co-existing independent communities or with a view

59. Art. IV, Section 1(i), Articles of Agreement.

60. Art. IV, Section 1(ii), Articles of Agreement.

61. Art. IV, Section 1(iii), Articles of Agreement.

62. Art. IV, Section 3(a), Articles of Agreement.

63. Ibid

64. Art. IV, Section 3(b), Articles of Agreement

65. Art. IV, Section 3(b), Articles of Agreement. As explained by the IMF's legal department in a 2006 analysis of the legal framework of Art. IV: 'While the present Article IV sets forth obligations of members, it also sets forth obligations for the Fund. Under Article IV, Section 3(a), the Fund is required to oversee the international monetary system to ensure its effective operation and to oversee the compliance of each member with its obligations under Article IV. Because of the particular importance of members' exchange rate obligations, the Articles give the Fund even more specific direction with respect to how members' compliance with these obligations is to be monitored: Article IV, Section 3(b), requires the Fund to exercise firm surveillance over the exchange rate policies of members and to adopt specific principles for the guidance of members with respect to those policies. To enable the Fund to perform its surveillance obligation, Article IV, Section 3(b), also requires each member to provide the Fund with the information necessary for this purpose and to consult with the Fund upon request.' to the achievement of common aims. Restrictions upon the independence of States cannot therefore be presumed. ${ }^{66}$

The aim of this section is to analyse the first of the conditions of legal legitimacy, departing from the assumptions that were made in the previous section. State consent, as already defined, comprehends the consent of a country to confer authority on an international organisation. For the purpose of the assessment, the validation of state consent is to determine whether member countries of the IMF have given their consent to receive tax recommendations from the Fund in the context of Article IV Consultations.

In an initial stage, state consent is given by countries by means of the signature and ratification of the treaties establishing an international organisation. Once the treaty enters into force, the powers that the corresponding organisation will have will depend on the text of the corresponding treaty or the interpretation given of the functions of the organisation, as per the theories on the capabilities of international organisations. Regardless, a fundamental proposition of legal legitimacy is that state consent continues to inform the authority exercised by international organisations throughout time.

Although repetitively stated, it is necessary to recall that the tax recommendations delivered by the Fund during Consultation Procedures are interpreted to derive, according to the IMF, from Article IV of the Fund's Articles of Agreement. Hence, for the Fund, the power that the organisation has to perform its surveillance procedures (including the tax issuance of the tax recommendations) has legal basis in this provision.

Furthermore, opinions issued within the IMF lead to the conclusion that in the opinion of the Fund's Executive Board, tax policies can be the subject of bilateral surveillance by the Fund, insofar as these are connected to the domestic stability of a member country. On 18 July 2012 the Fund's Executive Board adopted the Decision on Bilateral and Multilateral Surveillance, in which it took the view that:

In its bilateral surveillance, the Fund will focus on those policies of members that can significantly influence present or prospective balance of payments and domestic stability. The Fund will assess whether exchange rate policies are promoting balance of payments stability and whether domestic economic and financial policies are promoting domestic stability and advise the member on policy adjustments necessary for these purposes. Accordingly, exchange rate policies will always be the subject of the Fund's bilateral surveillance with respect to each member, as will 
monetary, fiscal, and financial sector policies... ${ }^{67}$ [emphasis added]

It is recognized that a member's overall mix of economic and financial policies, including both exchange rate and domestic policies, contributes to the members' balance of payments stability and domestic stability and may impact the stability of the international monetary system. ${ }^{68}$

Accordingly, the issuance of tax recommendations by the Fund during a Consultation is considered by the organisation as derived from the general obligations foreseen in Article IV of the Articles of Agreement, which bind member countries to 'endeavor to direct [their] economic and financial policies toward the objective of fostering orderly economic growth' and to 'seek to promote stability by fostering orderly underlying economic and financial conditions'. ${ }^{69}$

In light of the theory of attributed powers, nevertheless, the powers of the IMF would be restricted to those explicitly conferred in the Articles of Agreement, and the text of Article IV does not indicate a right of the IMF to oversee countries' tax policies. Therefore, the understanding of the IMF cannot be accepted under this theory.

Taking recourse to the theory of implied powers provides a wider interpretation of the powers of the Fund. Hence, it could be argued that i) tax policies heavily influence countries' economic growth and stability; and ii) public finances comprehend taxation and, therefore, the surveillance of tax issues falls within the authority of the IMF.

This approach, however, raises questions about the interpretation of the general obligations established in Article IV. Particularly, what specific actions should member countries take in order to comply with these general obligations? ${ }^{70}$

67. 2012 Decision, above n. 7. This decision repeals Decision N. 13919(07/51), adopted by the Executive Board on 15 June 2007. Guidance note EBS/97/125, issued on 2 July 1997 by the IMF, may be also regarded as creating a precedent for the Executive Board's opinion on their role to assess country's tax matters. In this guidance note, the Board indicates that '....the Fund should be concerned with issues such as institutional reforms of the treasury, budget preparation and approval procedures, tax administration, accounting, and audit mechanisms, central bank operations, and the official statistics function. Similarly, reforms of market mechanisms would focus primarily on the exchange, trade, and price systems, and aspects of the financial system. In the regulatory and legal areas, Fund advice would focus on taxation, banking sector laws and regulations...' [emphasis added].

68. Ibid

69. Art. IV, Section 1(i), Articles of Agreement.

70. In 2006, the IMF's Legal Department, in consultation with the Policy Development and Review Department, issued the report Article IV of the Fund's Articles of Agreement: An Overview of the Legal Framework (hereinafter 2006 Decision) aimed at 'assist[ing] the Executive Board in its consideration of the steps that could be taken to provide members with more specific guidance as to their obligations under Article IV.' In this document, the Legal Department recognises that any interpretation of Article IV would be a challenging mission, given that the substance of the Article was negotiated by a small number of member countries with underlying political reasons, outside the Executive Board. The document also makes clear that certain executive directors and staff criticised the Article on the grounds of its ambiguity and vagueness.
Article XXIX of the Articles of Agreement establishes the procedure to be followed when a question of interpretation of the provisions of the agreement arises between any member country and the Fund or between any of its members. Article XXIX, nevertheless, does not clearly indicate how member countries of the Fund or its organs (in application of the treaty provisions) should give meaning to the terms of the treaty. ${ }^{71}$ Article 31 of the Vienna Convention on the Law of Treaties must be used as ancillary provision to fill the legal vacuum of the Articles of Agreement in this regard. ${ }^{72}$ In conformity with Article 31, para. 1, of the Vienna Convention: 'A treaty shall be interpreted in good faith in accordance with the ordinary meaning to be given to the terms of the treaty in their context and in the light of its object and purpose.' [emphasis added] ${ }^{73}$

In connection, the scopes of the obligations in Section 1 of Article IV are to be interpreted in conformity with the general object underlying the constituency of the Fund. The purposes of the IMF are regulated under Article I of the Articles of Agreement. ${ }^{74}$ A reading of this provision leads to the conclusion that the members of the Fund have not intended for the organisation to have powers that enable it to dictate the national tax policies to be implemented by member countries. This conclusion may also be deducted when considering IMF documents that clearly indicate that 'although the text of the preamble does not give rise to obligations, it can be used as a tool to interpret those obligations that are set forth in Article IV, Section 1. Similarly, it provides a useful means of understanding the scope of the Fund's surveillance responsibilities under Article IV, Section 3'. 75

Finally, it could be argued that the power of the IMF to conduct surveillance of tax matters is connected to the general functions and work of the organisation. This approach seems to have been used in the past by the Fund, which has recognised that: 'In reality, all policies contribute to a country's internal and external balances and may ultimately impact global stability. Ultimately, what matters is the policy mix. ${ }^{76}$ Particularly, in 2015 the IMF issued guidance for staff to conduct Article IV surveillance, stating that:

Article IV consultations should cover all economic and financial policies that affect the member's own stability. These always include exchange rate, monetary, fiscal and financial sector policies. (...) Appropriate fiscal policy is vital to maintain a country's domestic and balance of payment stability, and often global stability. Threats to stability can result directly from fiscal policy missteps. Equally important, fiscal policy is often part of the policy mix to address macro-criti-

71. See Annex 1.

72. Vienna Convention on the Law of Treaties, 23 May 1969, 8 ILM 1969, at 679 (hereinafter 'Vienna Convention')

73. Art. 31 (1), Vienna Convention.

74. See Annex 1.

75. 2006 Decision, above n. 70

76. 2012 Decision, above n. 7. 
cal challenges that are not necessarily directly related to public finances (e.g., slow gromth, high unemployment, and inequality). [emphasis added $]^{77}$

In spite of the above, although the IMF was one of the international organisations created at the Bretton Woods Conference to avoid the global economic and financial crisis seen in previous years, the effects that national policies have nowadays on global stability cannot be easily contained. National tax policies continue to be part of the state's autonomy and, although the IMF may wish to control the corresponding spillovers by dictating the policies that should be implemented by its member countries, it does not have the consent of its member countries to do so. To that extent, the use of the theory of implied powers would also be insufficient to argue that the IMF has power to issue tax recommendations during an Article IV procedure.

In conclusion, the general obligations deriving from Section 1 of Article IV cannot be interpreted in a manner that enables the Fund to determine what should be the design of a country's tax system or the tax policies that the country should adopt, as these are prerogatives of a country's tax autonomy. A broad interpretation cannot constitute an instrument allowing international organisations to perform actions that are beyond the scope of the agreements reached by their constituent members.

It is also concluded that the Fund has accidentally or intentionally forgotten its obligations under the Articles of Agreement, since Article IV states that the guiding principles adopted by the IMF, pursuant to the same provision, '(...) shall respect the domestic social and political policies of members, and in applying these principles the Fund shall pay due regard to the circumstances of members'. ${ }^{78}$

\subsubsection{Authority}

In line with the assumptions explained in Section 3.1, legal legitimacy may be determined taking into consideration two sine qua non conditions: state consent and authority. ${ }^{79}$ These conditions operate concomitantly: state consent enables authority, and the absence of the former invalidates the latter.

For the purpose of this contribution, the assessment of authority aims to determine whether the IMF has the power to make tax recommendations to its member countries during Article IV Consultations. The exami-

IMF, Guidance Note for Surveillance under Article IV Consultation (2015)

78. Art. IV Articles of Agreement. This respect to the domestic social and political policies of members is also recognised by the Fund in the 2012 Decision, which further clarifies that: ' $[M]$ embers have legitimate policy objectives, including domestic social and political policy objectives, that are beyond the scope of Article IV and, accordingly, beyond the scope of this Decision, although when adopting policies to achieve these objectives, members need to ensure that such policies are consistent with their obligations under Article IV...[This] decision does not, and cannot be construed or used to, expand or broaden the scope - or change the nature - of members' obligations under the Articles of Agreement, directly or indirectly....

79. Also see Annex 2 nation of state consent, however, yielded negative results. I have mainly assessed that member states of the IMF have not given their consent to receive tax recommendations from the Fund, provided that the powers contained in Article IV of the Articles of Agreement are restricted to economic and financial matters. Under these circumstances, the question of whether the IMF has the authority to deliver the corresponding tax advice must also be answered negatively. The acts by the IMF towards the issuance of the said advice can be qualified as resulting from an abuse of authority to that effect.

\subsection{Looking Ahead}

Legitimacy, as developed by Thomas Franck, is a matter of degree. ${ }^{80}$ As a result, the legitimacy deficiency that has been identified as conflicting with legal legitimacy does not necessarily imply that the recommendations delivered by the Fund in the Consultations are wholly illegitimate. Accordingly, the aim of this contribution is not to seek to strike out these recommendations. On the contrary, the objective of the above discussion is to highlight matters that, in the current circumstances, entail a weakening of the legitimacy of the tax recommendations examined and, to a certain extent, of the Consultations themselves.

In light of the assessment, I believe that the issue arising from the non-existence of state consent and legal legitimacy could be solved with an amendment to Article IV of the Fund's Articles of Agreement. Such an amendment would be aimed at including, within the text of this provision, the powers and rights of the IMF to oversee and issue recommendations on national tax policy.

Looking ahead, the following list also presents a number of related topics that could be explored in the future:

- Can the continuing practice of the IMF, regarding the delivery of tax recommendations, consolidate the acts of the organisation as customary law?

- Under the current state of things, what would be the legal validity of tax surveillance by the IMF if it were concluded that it was performed ultra vires? ${ }^{81}$

- What procedures would be available to states to object to the acts by the IMF concerning tax surveillance? And what would be the convenience of having an appellate body that ultimately revises the decisions by the IMF?

\section{Concluding Remarks}

This contribution has aimed to assess the legitimacy of tax recommendations made by the IMF to member countries in the context of bilateral surveillance proce-

80. T. Franck, 'Legitimacy: A Matter of Degree', in T. Franck (ed.), The Power of Legitimacy among Nations (1990) 41, at 47.

81. See E. Osieke, 'The Legal Validity of Ultra Vires Decisions of International Organizations', 77 The American Journal of International Law 239 (1983); E. Cannizzaro and P. Palchetti, 'Ultra Vires Acts of International Organizations', in J. Klabbers \& A. Wallendahl (eds.), Research Handbook on the Law of International Organizations (2011). 
dures, known as 'Article IV Consultations'. As explored, although the IMF has the powers to evaluate the economic and financial situation of a country, these powers do not enable it to give tax recommendations to its member countries as there is no state consent in this regard. In conclusion, the legal legitimacy (as a means of achieving a connection between state consent and an institution's continuing authority) of the tax recommendations is considered precarious. This is particularly relevant insofar as the tax recommendations delivered by the Fund touch upon fundamental aspects of the design of national tax systems and must be regarded as prerogatives linked to countries' tax autonomy.

On a side and final note, I believe that the conflicting issue that has been raised should be considered not only from a legal legitimacy perspective, but also in regard to the legitimacy of the outcomes produced - that is, against the medium- and long-term economic and social consequences that the adoption of certain recommendations could have. ${ }^{82}$ In this sense, even if it could be argued that the tax recommendations are legitimate, these recommendations should be based on a countryspecific analysis. Such an analysis would allow the Fund and the corresponding country to determine the specific consequences that the policies under review will have for the country's situation. This, in turn, will enable compliance with the provision in Article IV regarding respect for member countries' domestic policies, which is precisely what countries agreed to when joining the IMF.

\section{Annex 1: Relevant provisions of the IMF Articles of Agreement}

\section{Article I: Purposes}

The purposes of the International Monetary Fund are:

i. To promote international monetary cooperation through a permanent institution which provides the machinery for consultation and collaboration on international monetary problems.

ii. To facilitate the expansion and balanced growth of international trade, and to contribute thereby to the promotion and maintenance of high levels of employment and real income and to the development of the productive resources of all members as primary objectives of economic policy.

iii. To promote exchange stability, to maintain orderly exchange arrangements among members, and to avoid competitive exchange depreciation.

This matter is an object of analysis under commonly known theories of 'output legitimacy'. For instance, see R. Wolfrum, above n. 40, at 7. For this author: 'If a particular body, such as the Security Council or an international court or tribunal, although established in accordance with the applicable rules and taking decisions according to the established procedure, does not achieve results which the community as the addressee of such decisions considers to be adequate, this may, in the long run, lead to an erosion of its legitimacy.' iv. To assist in the establishment of a multilateral system of payments in respect of current transactions between members and in the elimination of foreign exchange restrictions which hamper the growth of world trade.

v. To give confidence to members by making the general resources of the Fund temporarily available to them under adequate safeguards, thus providing them with opportunity to correct maladjustments in their balance of payments without resorting to measures destructive of national or international prosperity.

vi. In accordance with the above, to shorten the duration and lessen the degree of disequilibrium in the international balances of payments of members.

The Fund shall be guided in all its policies and decisions by the purposes set forth in this Article. ${ }^{83}$

\section{Article IV: Obligations Regarding Exchange Arrangements}

\section{- Section 1: General Obligations of Members}

Recognising that the essential purpose of the international monetary system is to provide a framework that facilitates the exchange of goods, services, and capital among countries, and that sustains sound economic growth, and that a principal objective is the continuing development of the orderly underlying conditions that are necessary for financial and economic stability, each member undertakes to collaborate with the Fund and other members to assure orderly exchange arrangements and to promote a stable system of exchange rates. In particular, each member shall:

i. endeavor to direct its economic and financial policies toward the objective of fostering orderly economic growth with reasonable price stability, with due regard to its circumstances;

ii. seek to promote stability by fostering orderly underlying economic and financial conditions and a monetary system that does not tend to produce erratic disruptions;

iii. avoid manipulating exchange rates or the international monetary system in order to prevent effective balance of payments adjustment or to gain an unfair competitive advantage over other members; and

iv. follow exchange policies compatible with the undertakings under this Section.

- Section 2: General Exchange Arrangements (a) Each member shall notify the Fund, within thirty days after the date of the second amendment of this Agreement, of the exchange arrangements it intends to apply in fulfillment of its obligations under Section 1 of this Article, and shall notify the Fund promptly of any changes in its exchange arrangements.

(b) Under an international monetary system of the kind prevailing on 1 January 1976, exchange arrangements may include (i) the maintenance by a member of a value

83. Art. I Articles of Agreement. 
for its currency in terms of the special drawing right or another denominator, other than gold, selected by the member, or (ii) cooperative arrangements by which members maintain the value of their currencies in relation to the value of the currency or currencies of other members, or (iii) other exchange arrangements of a member's choice.

(c) To accord with the development of the international monetary system, the Fund, by an eighty-five percent majority of the total voting power, may make provision for general exchange arrangements without limiting the right of members to have exchange arrangements of their choice consistent with the purposes of the Fund and the obligations under Section 1 of this Article.

- Section 3: Surveillance over Exchange Arrangements (a) The Fund shall oversee the international monetary system in order to ensure its effective operation, and shall oversee the compliance of each member with its obligations under Section 1 of this Article.

(b) In order to fulfill its functions under (a) above, the Fund shall exercise firm surveillance over the exchange rate policies of members, and shall adopt specific principles for the guidance of all members with respect to those policies. Each member shall provide the Fund with the information necessary for such surveillance, and, when requested by the Fund, shall consult with it on the member's exchange rate policies. The principles adopted by the Fund shall be consistent with cooperative arrangements by which members maintain the value of their currencies in relation to the value of the currency or currencies of other members, as well as with other exchange arrangements of a member's choice consistent with the purposes of the Fund and Section 1 of this Article. These principles shall respect the domestic social and political policies of members, and in applying these principles the Fund shall pay due regard to the circumstances of members.

\section{- Section 4: Par Values}

The Fund may determine, by an eighty-five percent majority of the total voting power, that international economic conditions permit the introduction of a widespread system of exchange arrangements based on stable but adjustable par values. The Fund shall make the determination on the basis of the underlying stability of the world economy, and for this purpose shall take into account price movements and rates of expansion in the economies of members. The determination shall be made in light of the evolution of the international monetary system, with particular reference to sources of liquidity, and, in order to ensure the effective operation of a system of par values, to arrangements under which both members in surplus and members in deficit in their balances of payments take prompt, effective, and symmetrical action to achieve adjustment, as well as to arrangements for intervention and the treatment of imbalances. Upon making such determination, the Fund shall notify members that the provisions of Schedule C apply.
- Section 5: Separate Currencies mithin a Member's Territories

(a) Action by a member with respect to its currency under this Article shall be deemed to apply to the separate currencies of all territories in respect of which the member has accepted this Agreement under Article XXXI, Section 2(g) unless the member declares that its action relates either to the metropolitan currency alone, or only to one or more specified separate currencies, or to the metropolitan currency and one or more specified separate currencies.

(b) Action by the Fund under this Article shall be deemed to relate to all currencies of a member referred to in (a) above unless the Fund declares otherwise. ${ }^{84}$

\section{Article XXIX: Interpretation}

(a) Any question of interpretation of the provisions of this Agreement arising between any member and the Fund or between any members of the Fund shall be submitted to the Executive Board for its decision. If the question particularly affects any member, it shall be entitled to representation in accordance with Article XII, Section 3(j).

(b) In any case where the Executive Board has given a decision under (a) above, any member may require, within 3 months from the date of the decision, that the question be referred to the Board of Governors, whose decision shall be final. Any question referred to the Board of Governors shall be considered by a Committee on Interpretation of the Board of Governors. Each Committee member shall have one vote. The Board of Governors shall establish the membership, procedures, and voting majorities of the Committee. A decision of the Committee shall be the decision of the Board of Governors unless the Board of Governors, by an eightyfive percent majority of the total voting power, decides otherwise. Pending the result of the reference to the Board of Governors the Fund may, so far as it deems necessary, act on the basis of the decision of the Executive Board.

(c) Whenever a disagreement arises between the Fund and a member which has withdrawn, or between the Fund and any member during liquidation of the Fund, such disagreement shall be submitted to arbitration by a tribunal of three arbitrators, one appointed by the Fund, another by the member or withdrawing member, and an umpire who, unless the parties otherwise agree, shall be appointed by the President of the International Court of Justice or such other authority as may have been prescribed by regulation adopted by the Fund. The umpire shall have full power to settle all questions of procedure in any case where the parties are in disagreement with respect thereto. ${ }^{85}$

84. Art. IV Articles of Agreement.

85. Art. XXIX Articles of Agreement. 


\section{Annex 2}

Figure 1 Legal legitimacy flow diagram

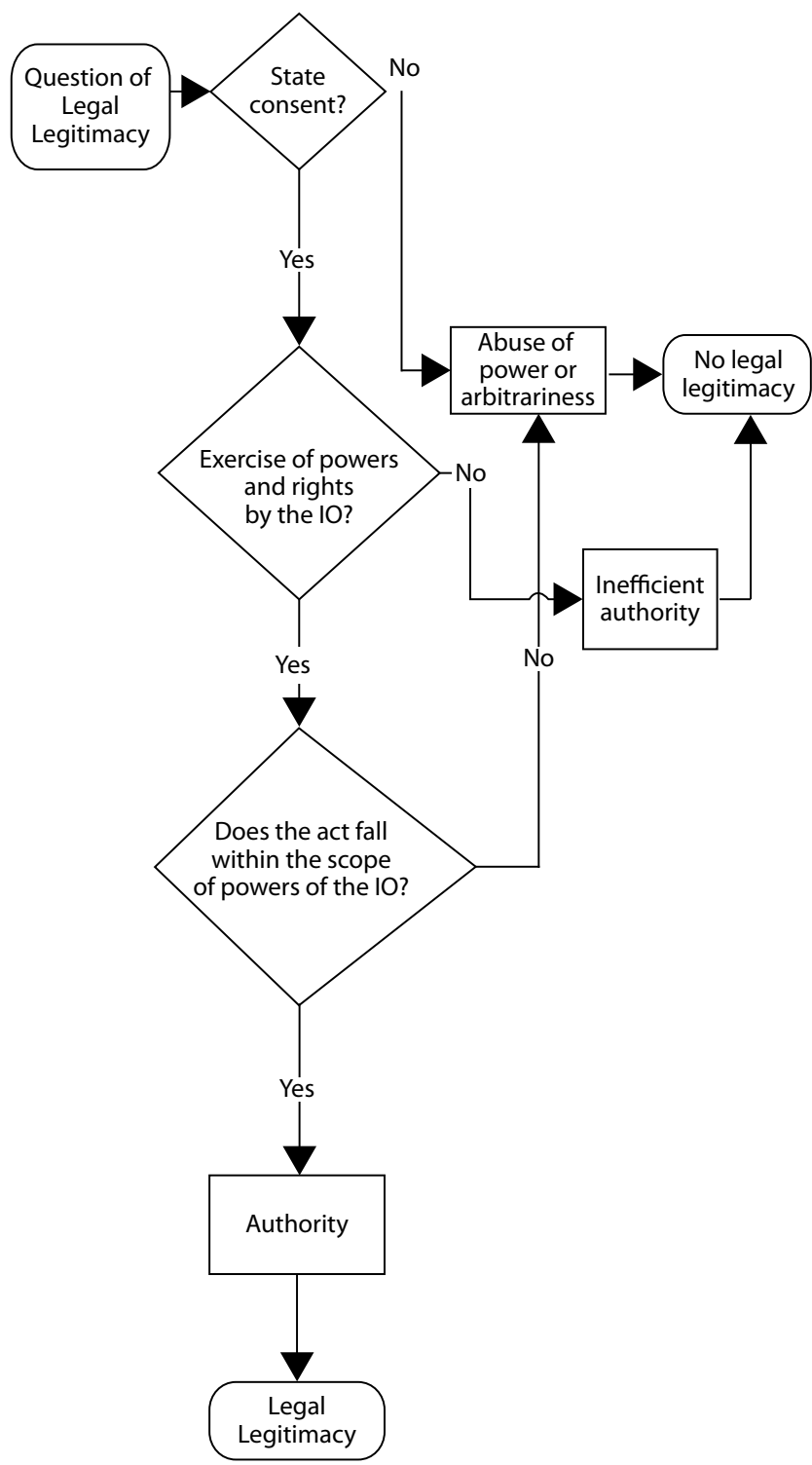

